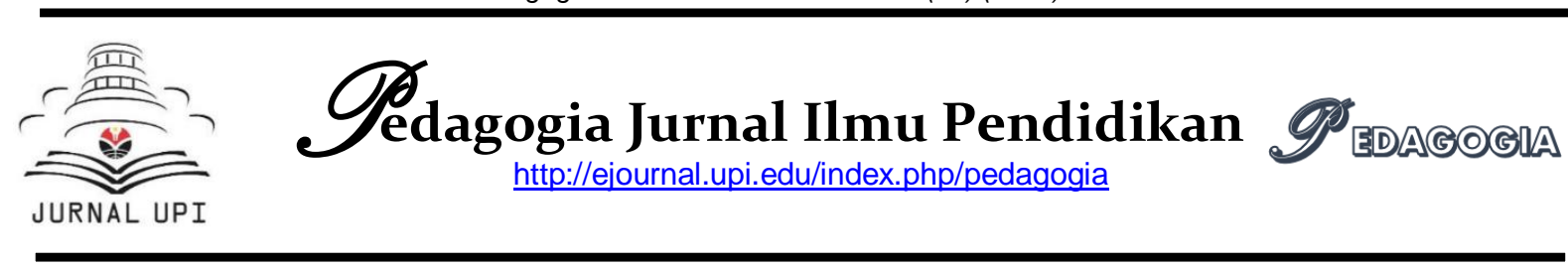

\title{
Open Classroom Climate: Project Citizen Model in Civic Education Learning Activity
}

\author{
Muhammad Mona Adha \\ Hermi Yanzi \\ Yunisca Nurmalisa \\ Universitas Lampung, Bandar Lampung, Indonesia \\ mohammad.monaadha@fkip.unila.ac.id
}

\begin{abstract}
Pembelajaran pendidikan kewarganegaraan berbasis portofolio berupaya untuk fokus pada siswa agar memiliki pengetahuan dan pemahaman, keterampilan dan sikap, nilai-nilai, dan disposisi yang mengarahkan mereka secara aktif berpartisipasi dalam berperan dan tanggung jawab di dalam kehidupan mereka sehari-hari. Project citizen memberikan keyakinan kepada siswa memiliki kemampuan untuk memberikan analisis masalah, mengumpulkan tugas, dan menjadi lebih kreatif. Iklim kelas terbuka menjadi faktor penting dalam membangkitkan motivasi dan minat siswa dalam pembelajaran pendidikan kewarganegaraan sehingga tercipta interaksi dan hubungan yang demokratis di dalam kelas. Penelitian kuantitatif dengan metode kuasi eksperimen dilakukan pada kelas eksperimen dan kelas kontrol sebanyak enam kali pertemuan (enam minggu) untuk melihat perbedaan implementasi diantara kedua kelas yang berbeda berdasarkan aspek motivasi, interaksi dan kerjasama di dalam kelompok. Temuan dari penelitian ini adalah: (1) pengalaman belajar yang terintegrasi memberikan kesadaran kepada siswa bahwa keseimbangan antara hak dan kewajiban sangat penting sebagai warga negara dan mencari solusi alternatif untuk penyelesaian masalah di sekitar siswa/masyarakat; (2) secara signifikan model belajar ini meningkatkan aktivitas kerjasama dan motivasi siswa.
\end{abstract}

Kata kunci: Pendidikan Kewarganegaraan, Iklim Kelas Yang Terbuka, Project Citizen

\author{
Article Info \\ Naskah Diterima : \\ 2018-11-11 \\ Naskah Direvisi: \\ 2019-03-19 \\ Naskah Disetujui: \\ 2019-04-26
}

\begin{abstract}
A b s trak
Civic education portfolio-based learning seeks to focus on students' ownership of knowledge and understanding, skills and attitudes, values, and dispositions that lead them to actively participate in their roles and responsibilities in their lives. Project citizen gives students confidence that students have the ability to provide problem analysis, collect tasks, and be more creative. The purpose of this research is to explore open classroom climate becomes an important factor in generating motivation and interest in students in civic education learning, thus creating democratic interaction and connection in the class. Quantitative research using the quasi-experiment method was conducted in the experimental class and the control class with a duration of six meeting to analyze the differences between the two classes in motivation, interaction, and teamwork activity aspect. The findings of this study are: (1) integrated learning experiences provide awareness to students that the balance between rights and obligations is very important as a citizen and look for alternative solutions to problems around the community; (2) significantly this learning technique increase student cooperation performance and motivation.
\end{abstract}

Keywords: Civic Education, Open Classroom Climate, Project Citizen 


\section{A. Introduction}

Civic education was developed as a central goal of the education system, required for all level of schools that apply learning with high quality and sufficient quantity, using an interdisciplinary approach and interactive learning methods (Adha et al., 2018; Halimah, 2018). Project based learning technique has a positive effect on motivation, performance, cooperation, skills, and knowledge for students in the class (Kose, 2010; Woods, 2014). Citizenship education must target the needs of students. They should not be given too many abstract things, but given real and useful things for everyday life. The social factor in school is the greatest factor of all; it stands higher than subjects of learning, rather than methods of teaching, or that the teacher. That which children learn from each other in play and works is the highest that is ever learned (mingling, fusing, and blending). Civic education is a basic subject that is designed to prepare young citizens to be able to play an active role in society, later after they grow up.

Project citizen developed by the Center for Civic Education (CCE), in the last few decades has been adopted by around 50 countries in the world, including Indonesia. This model is generic or general and fundamental which contains material based on the characteristics of each country. Project citizen prioritizes generic issues, especially public policies that are applicable in any country. The mission of this model is to educate students to be able to analyze various dimensions of public policy, then with their capacity as "young citizens" trying to provide input on public policy in their environment (Nusarastriya etal., 2013). The expected results are the quality of citizens who are intelligent, creative, participatory, prospective, and responsible (Banks, 2014; Trisiana, 2015: Halimah, 2018). Project-based learning is convenient for an interdisciplinary course because naturally it involves different academic skills such as reading, writing, and math (Susilawati et al., 2017). In general, the topics of project based learning are actually very useful to study and be able to increase knowledge, skills and attitudes in interacting both in school and in the community (Kose, 2010).

Project Citizen is intended to enable students to understand important public policy issues in their own communities, government and non-government organizations by contributing to solving public policy problems based on democratic governance (Adha et al., 2018; Adha \& Yanzi, 2014; Adha, 2010). One program in citizenship education called Project Citizen, was developed by taking into account (1) instructions based on children's desires; (2) students learn cooperatively; (3) citizenship education relates to social experience. Project Citizen is an example to develop ideas in the world of education by looking at the problems around students based on six steps in the process of implementing the learning. This research has highlighted the citizen learning project model to contribute to open classroom climate in order to students who will be engaged with the entire activities (Adha \& Yanzi, 2014). Portfolio-based in civic education learning focuses on the process of constructing student analysis of knowledge and understanding, skills and attitudes, values, and dispositions that lead them to actively participate in their roles and responsibilities in their lives.

Portfolio-based in civics learning, students are not only provided with citizenship knowledge, but also how to obtain this knowledge through the process of constructing knowledge through activities while learning while working, active experience and participation in schools and communities. So that portfoliobased civics learning not only develops civic knowledge, in the form of knowledge 
and understanding of national history, governance structures and processes and political life, but also civic skills, in the form of critical thinking skills, participation skills, and social skills, and civic disposition in the form of attitudes and commitment that is important for citizenship through active and participatory activities in direct experience in class, school and community (Adha et al., 2014). Through portfolio-based in civics learning, citizenship education is associated with the whole education experience students. Citizenship Education is the more inclusive term of both these in-school experiences as well as out-of-school or informal learning which takes place in the family, the religious organization, the community organization, the media etc. to emerge individual and community engagement" (Cogan, 1998).

\section{B. Literature Review}

\section{Civic Education Open Classroom Climate}

Civics teachers must understand: (a) various types of teaching techniques, (b) the relationship of civics learning materials with other social sciences (c) the community environment, religion, science and technology, and (d) different student backgrounds. The teacher must integrate memorization with the real life in the community so that students are trained to think, behave, and act democratically in the classroom and in society. In other words, the teacher trains students to find consensus in the life of a democratic society.

Citizenship education in practice emphasizes the formation of citizen empowerment processes, so that they are able to play a role as government partners in carrying out social, national and state duties. Citizenship education empowers students to be human beings who are dignified, competition, and provide benefits to life in society. In this position the learning of citizenship education is more open classroom climate to strengthen individual integrity (truth, justice, honesty).

Civic Education develops a state of mind, building national character is a process of forming citizens who are intelligent and have high reasoning power. Civic education focuses on the formation of civic intelligence, civic responsibility, and civic participation as the basis for developing democratic values and behavior. Democracy is developed through the expansion of insight, development of analytical skills and social sensitivity for citizens so that they can solve with realistic environmental problems solving.

\section{Focusing on Project Citizen}

Education referred to by Parker (progressive education era) is education centered on students by walking naturally, and lead to curiosity of students. Parker said that the most important resources at any school are the students themselves. Basically, Project Citizen has been discussed in the era of progressive education philosophy in American history, especially in the late 19th century until the beginning of the 20th century. Many theories and practices of education are classified in the progressive era based on the ideas of Francis Parker, John Dewey, and William Heard Kilpatrick who directly link goals, rational, material concepts, and pedagogy from Project Citizen.

Parker believes that the community of children is a very important potential especially for citizenship education. Students learn civic education spontaneously and naturally in interactions and relationships between individuals. Social relations could emerge the student sense of responsibility.

Problem solving based on the citizenship education program which was later called Project Citizen was 
implemented by developing (1) instruction based on the desires of children; (2) cooperative learning; (3) related to social experience. Project Citizen is one example to develop ideas in the world of education to determine the best solution, rational based on the steps of the Project Citizen program.

Project Citizen is held in Middle School on the following considerations: The middle school years are an especially crucial time to the development of civic roles and responsibilities. During this years, students are discovering their identities and their large roles in their communities and in society in a whole. However, little attention has been aimed at promoting citizenship during these formative middle school years (Tolo in Winataputra, 2001).

\section{Research Methods}

Research with the quasi experiment method is carried out to obtain information obtained by actual experimental, in a situation that is not possible to control or control all variables (Campbell \& Stanley, 2015). A description of the implementation of the citizen project model to improve citizenship skills in the situation open climate classroom used a quasiexperiment method with a randomized control group design pre-test - post-test design. The samples were divided into 2 groups, namely one experimental group and one control group. The experimental group gets learning with the project citizen model while the control group gets conventional model learning. The two groups performed a pre-test, post-test to see the effect of learning with the project citizen model.

The implementation of the project citizen model is carried out in a predetermined class. This stage begins with a pre-test to find out the initial ability of students, then given treatment in the form of applying a project citizen model and ending with a post-test.

Furthermore, students were asked to fill out a questionnaire and conducted interviews with several students to find out the interests, motivations and responses of students to the media applied in learning. The final step is to analyze the data and findings obtained in the form of data for the preparation of research findings.

Information, data and documents that have been collected are then analyzed using the results of pre-test and post-test, testing the hypothesis with t-test calculations. The calculation results were analyzed and described to explain the differences between the experimental class and the control class based on the six steps team working in project citizen.

\section{Result and Discussion \\ 1. Project Citizen Model Implementations}

Project citizen model is a civic education learning package designed to develop students' interests, abilities, level of participation, improve experience, and have an attitude of responsibility in class activities (Adha et al., 2014; Trisiana, 2015; Mulyoto \& Samsuri, 2017; Adha et al., 2018). Civic education, in its ideal form, to engage students in their communities by teaching them the skills necessary to effectively participate in communities. In a constitutional democracy, the importance of civic education cannot be overstated. Effective citizenship education that teaches people how to participate in and effect positive change within their communities is critical to the development of a lasting commitment to civic participation (Tolo, 1998). There are several basic principles of portfolio-based learning models, namely: 1 ) student active learning; 2) cooperative learning; 3) participatory learning; 4) 
reactive teaching; 5) democratic learning (Budimansyah, 2002).

Branson in Budimansyah (2008) suggests that the project citizen's rationale lies in a framework consisting of five parts of educational and political ideas. First, democracy requires self-government and therefore requires active involvement and citizens who are knowledgeable in state life. An indispensable component of citizen involvement is participation in the public policy-making process. Second, students must learn how to become involved in community life activities, namely by being responsible and effective citizens. Third, because students explore the problems that exist in their own communities, they have many opportunities to consider the basic things at the core of democracy, such as those which include individual rights and common interests, rules agreed upon by the majority group and the rights of minorities, and freedom and equality.

Fourth, project citizen is intended to be applied primarily by middle school students or teenagers (aged around 10-15 years); but the program is also used by older adolescents in some schools. In high school age, students try to form their own identity and they must also be given the opportunity to build relationships with the community. Most of the early adolescents (early adolescents) began to shift from concrete thinking to abstract thinking and often faced with problems of good and bad, legitimacy of authority (right or not the right to act), and alternative answers to difficult situations. During adolescence, students shape attitudes and accept values they are likely to hold throughout life. Students tend to want to know about the environment around them, including their community as citizens and they need real-world experiences to explore their relationship with their life (Fry \& Bentahar, 2013; Nusarastriya et al., 2013; Adha \& Yanzi, 2014). Fifth, project citizen considers young people as a source of citizenship, as valuable members of their valuable community, having ideas and energy to be truly devoted to understanding and finding alternative solutions in matters of public policy. Project Citizen requires students to take part as citizens. According to project citizen developers, participation like this is not only a better vehicle to increase the knowledge, skills and character of citizenship (Atherton, 2000; Vontz, 2000; Kerr, 2018), but also better for the community because these students make it easier government and civil society organizations work through important issues in society (Adha \& Yanzi, 2014). Participation and involvement like this should help young people build relationships with communities where they live and appreciate their contribution to solving problems in the community (Fry \& Bentahar, 2013; Erhamwilda, 2014; Adha \& Yanzi, 2014; Alfiyansah, 2016).

Table 1

Six Steps Of Project Citizen Model Implementation

\begin{tabular}{lll}
\hline \multicolumn{1}{c}{ Steps } & \multicolumn{1}{c}{ Activities } & Working \\
\hline $\begin{array}{l}\text { Identifying public policy problems } \\
\text { in communities }\end{array}$ & $\begin{array}{l}\text { Discuss with friends about the topic } \\
\text { Sharing the story about the problems }\end{array}$ & Classroom \\
$\begin{array}{l}\text { Selecting a problem for class } \\
\text { study }\end{array}$ & $\begin{array}{l}\text { Make an analysis related to the } \\
\text { problem } \\
\text { Each student choose the interest one } \\
\text { of the topic }\end{array}$ & Classroom \\
\hline
\end{tabular}


Gathering information on the
problem

Developing a classs portfolio

Presenting the portfolio

Reflecting
Collecting information from newspaper Information and data from the books Interview with parents, teacher, or staff

Preparing all material include data and information

Creative design for panel presentation Arrangement all the documentation

One speaker to make a presentation Question and answer with the judges

Make an evaluation based on their work

Sharing the experience and problem solving for the future
Library Communities

Institutions

Classroom library

Classroom

Auditorium

Classroom
The portfolio-based learning process is student-centered to be more active (Adha \& Yanzi, 2014; Rahayu \& Setiyadi, 2018; Adha et al., 2018). Students are involved in learning activities starting from planning especially when students are brainstorming. Each student may convey interesting problems related to the subject matter. After the problem is collected, students vote for a problem for class study. In the stage of collecting outside school hour information and data, student activities are more visible. With various techniques (for example by interviews, observations, questionnaires, etc.) they collect data and information needed to answer the problems that become the class study material. Completing the data and information, they take photos, make sketches, and prepare clippings. At the reporting stage, student activities are focused on making class portfolios. Various data and information that can be then systematically compiled and documented.

The next process is to create a portfolio that will be presented in front of the judges. Data and information that has been collected is made interesting and posted on the portfolio panel made of cardboard or other materials. After the portfolio is completed, a public hearing is held in the showcase activity before the jury. The showcase is the peak performance of students, because at this stage, the results of student work will be tested and debated before the jury. And as the final step of project citizen is a reflection of the learning experience.

The portfolio-based learning process applies the principle of cooperative learning, namely building student collaboration. Collaboration is carried out between students and their teachers, including school collaboration with certain parents and institutions. Cooperation provides opportunities for students to learn by doing. One form of treatment is that students learn democratic life. When choosing a problem for class study material, it appears that students respect each other for decisions made by their classmates. Collaborative activities such as discussion, expressing opinions, hearing the opinions of others, expressing criticism and conversely learning to accept criticism, students are actively involved in participating in the learning process (Rahayu et al., 2014).

The teacher needs to create the right strategy so that students have high learning motivation (Nuraeni, 2016). Such motivation will arise if the teacher can convince students that the material being learned is useful for real life (Alfiyansah, 
2016). Then, the teacher explains and creates an interesting and not boring class situation. Civics education is a learning of democracy in order to develop the attitude of students to be democratic citizens, smart and good citizenship, responsible, civic engagement, and morality (Nurmalisa \& Adha, 2016). Civic education class with the concept of democratic learning is more related to social issues or problems which aim to develop knowledge, skills, disposition of citizenship and participation in government including civil society.

\section{Students' active participation with Project Citizen model implementation}

The project citizen provides an opportunity for students to give their opinions and get the widest opportunity to work together with other group members. This model is able to increase student participation which can be seen from the results of questionnaires distributed to students. In general, students say that this model is very interesting and creates a more pleasant classroom atmosphere. This learning model increases overall student participation and is active in the classroom and prepares the portfolio.

Table 2

Participatory Skills Pre-Test And Post-Test

\begin{tabular}{llcccc}
\hline \multirow{2}{*}{ No } & \multirow{2}{*}{ Indicator } & \multicolumn{3}{c}{ Experiment class } \\
\cline { 3 - 6 } & & \multicolumn{2}{c}{ Pre-test } & \multicolumn{2}{c}{ Post-test } \\
\cline { 3 - 6 } & & Averag & $\%$ & Averag & $\%$ \\
& & e & \\
\hline 1 & Participator & 4.15 & 49.6 & 4.19 & 50.3 \\
& y skills & & 4 & & 8 \\
\hline 2 & Problem & 4.21 & 50.3 & 4.26 & 50.4 \\
& solving & & 6 & & 5 \\
& skills & & & & \\
\hline
\end{tabular}

Table 3

Participatory Skills Post Test (Experimen (Experiment And Control Class)

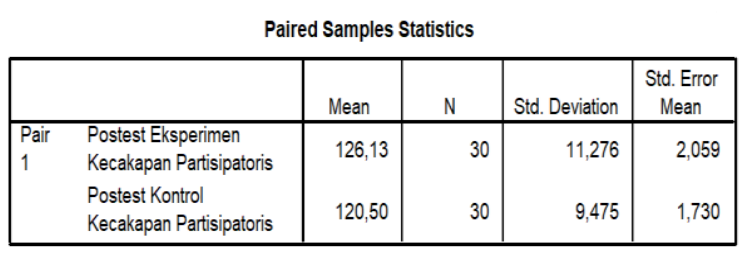

The strong influence significantly between citizen project models in improving citizenship skills can be analyzed from several things: First: citizen project models are natural for students. That is, providing opportunities for students to practice critical thinking, interact and discuss with classmates, negotiate, cooperate and make the best decisions for the public interest. The citizen project provides experience to students to construct knowledge and develop the ability to remember and express student experiences, the ability to compare and make decisions, and the ability to like one experience to another experience.

The mission of this model is to educate students to be able to analyze various dimensions of public policy, then with their capacity as "young citizens" or young citizens trying to give input to public policies in their environment. The expected results are the quality of citizens who are "intelligent, creative, participatory, prospective, and responsible." The basis of developing portfolio-based learning models is constructivism learning theory, which in principle illustrates that students form or build their knowledge through interaction with their environment. The most common and most essential principle that can be derived from constructivism, namely that knowledge is built by humans little by little.

Learning must provide an opportunity to collaborate on their learning experiences: achievement, social awareness, and the learning result (Matroji, 2016). The main principle of learning is the 
process of involvement of all or part of a student's self potential and also it's meaning for himself and his life. Portfoliobased learning that applies the concept of interrelation between concepts in the reality of student life. Learning is a meaningful assimilation for students, the material being studied is assimilated and associated with the knowledge that students already have in the form of cognitive structures which are organizational structures that exist in a person's memory that integrate separate elements of knowledge into a conceptual unit.

The project citizen model challenges students to be actively involved in government and community organizations, uncovering various problems at school and in the surrounding community and obtaining the intellectual resources needed for democratic and responsible citizenship (Adha \& Yanzi, 2014). Furthermore, this learning model is intended to encourage and empower students to exercise their rights and responsibilities. Furthermore, this learning model is intended to encourage and empower students to exercise their rights and responsibilities as democratic citizens through the intensive study of public policy issues both at school and in the community. Learning materials are designed to help students learn to supervise and influence public policy, develop skills needed by a responsible citizen, and be confident in exercising citizenship rights and responsibilities. The portfolio-based in civics learning model provides opportunities for young people to participate in government and civil society by practicing critical thinking, dialogue, debating, negotiating, cooperating, behaving politely and politely, being tolerant, making decisions, and taking actions related to civic action for the common good.

\section{E. Conclusions}

Project citizen focus on the skills needed for responsible, effective and scientific participation, in the political process and in civil society. Interaction is related to the skills of citizens in communicating and collaborating with others. Interaction means asking, answering and negotiating politely, as well as building coalitions and managing conflicts in a peaceful and honest manner. Project citizen prioritizes student participation in various life activities in community, nation and state. Participation in the form of mind is carried out through the contribution of ideas to solve the problems faced together for the common good. The strong influence significantly between project citizen model to improve citizenship skills through natural activity. This technique providing opportunities for students to practice critical thinking, interact and discuss with classmates, negotiate, cooperate and make the best decision for the public interest. The concept of cooperation is a national cultural value known as mutual assistance and musyawarah. Thus cooperation is social capital that already exists in students that must be explored and optimized in learning process in the classroom. 


\section{References}

Adha, M. M. (2010). Model Project Citizen untuk meningkatkan kecakapan warga Negara pada konsep kemerdekaan mengemukakan pendapat. Jurnal Kultur Demokrasi, 1 (8): 44-52.

Adha, M. M \& Yanzi, H. (2014). Project Citizen Model for Effective Student Engagement and Democratic Citizenship in Civic Education Best Practices. The First Sriwijaya University Learning and Education International Conference Proceedings. Faculty of Teacher Training and Education Sriwijaya University.

Adha, M. M., Yanzi, H, \& Nurmalisa, Y. (2018). The Improvement of Student Intelectual and Participatory Skill through Project Citizen Model in Civic Education Classroom. International Journal Pedagogy of Social Studies, 3 (1): 39-50.

Alfiyansah, R. (2016). Penggunaan Media Pembelajaran I-Spring Presenter Untuk Meningkatkan Motivasi Belajar Dan Hasil Belajar Pada Mata Kuliah Keperawatan Dasar Nutrisi. Pedagogia: Jurnal IImu Pendidikan, 14 (2): 363-369.

Atherton, H. M. (2000). We the people ... project citizen. (Ed), Mann, S. \& Patrick, J. J. Education for civic engagement in democracy: Service learning and other promising practices. Indiana: ERIC Clearinghouse for social studies/social science education.

Banks, J. A. (2014). Citizenship Education and Diversity Implications for Teacher Education. Journal of Teacher Education. 52 (1): 5-16.

Budimansyah, D. (2008). PKN dan Masyarakat Multikultural. Bandung: Program Studi PKn SPs UPI.

Budimansyah, D. (2002). Model Pembelajaran dan Penilaian Berbasis Portofolio. Bandung: PT. Ganesindo.

Campbell, D. T. \& Stanley, J. C. (2015). Experimental and Quasi-Experimental Designs for Research. Retrieved from https://books.google.co.id/books.

Cogan, J.J. (1998). Citizenship for the 21st Century: An International Perspective on Education. London: Kogan Page Limited.

Erhamwilda. (2014). Peer Counseling Model for Improving Students' Self-Direction Competence. International Journal of Education, 7 (2): 84-96.

Fry, S. W. \& Bentahar, A. (2013). Student Attitudes Towards and Impressions of Project Citizen. Journal of Social Studies Education Research, 4 (1): 1-23.

Halimah, L. (2018). Pengaruh Pembelajaran Pendidikan Kewarganegaraan Terhadap Nasionalisme Peserta Didik Sekolah Menengah Kota Cimahi. Pedagogia: Jurnal IImu Pendidikan, 16 (3): 209-224.

Kerr, D. (2018). Citizenship Education: an International Comparison. Retrieved from http://www.seameo.org/SEAMEO.

Kose, U. (2010). A web based system for project-based learning activities in "web design and programming" course. Procedia - Social and Behavioral Sciences, 2, (2): 1174-1184.

Matroji. (2016). Penerapan Model Group Investigation untuk Meningkatkan Hasil Belajar Siswa Dalam Pembelajaran Sejarah Materi Pengaruh Sejarah Dunia Terhadap Sejarah Bangsa Indonesia Abad 18-20. Pedagogia: Jurnal IImu Pendidikan, 14 (2): 356-362.

Mulyoto, G. P. \& Samsuri, S. (2017). Pengaruh model project citizen dengan pendekatan saintifik terhadap penguasaan kompetensi kewarganegaraan dalam pembelajaran 
Pendidikan Pancasila dan Kewarganegaraan. Jurnal Civics: Media Kajian Kewarganegaraan, 14 (1): 105-118.

Nurmalisa, Y \& Adha, M. M. (2016). Peran Lembaga Sosial Terhadap Pembinaan Moral Remaja Di Sekolah Menengah Atas. Jurnal IImiah Pendidikan Pancasila dan Kewarganegaraan, 1 (1): 64-71.

Nuraeni. (2016). Meningkatkan Kualitas Belalar Mengajar Di Sdn Sukajadi Dengan Penerapan Cooperative Learning Teknik Kepala Bernomor Struktur Pada Semester Genap Tahun Pelajaran 2014/2015. Pedagogia: Jurnal IImu Pendidikan, 14 (3): 443457.

Nusarastriya, Y. H. S., Sapriya., Wahab, A. A. \& Budimansyah, D. (2013). Pengembangan berpikir kritis dalam pembelajaran pendidikan kewarganegaraan menggunakan project citizen. Cakrawala Pendidikan: Jurnal Ilmiah Pendidikan, 3 (3).

Rahayu, G. D. S. \& Setiyadi, R. (2018). Penerapan Model Project Citizen dalam Upaya Meningkatkan Kecerdasan Ekologis. Mimbar Sekolah Dasar, 5 (1): 31-42.

Rahayu, A., Suwatno, Suherman, A., \& Yuliawati, A. K. (2014). Analysis of Resources-Based Education Management and Its' Effect on School Advantage. International Journal of Education, 7 (2): 97-102.

Susilawati, A., Hernani, \& Sinaga, P. (2017). The application of project-based learning using mind maps to improve students' environmental attitudes towards waste management in junior high schools. International Journal of Education, 9 (2): 120-125.

Tolo, K. W. (1998). An Assesment of We the People Project Citizen: Promoting Citizenship in Classroom and Communities. Austin: The Boards of Regents University of Texas.

Trisiana, A. (2015). Action for citizenship education of character education using project citizen model at senior high school in Indonesia. International Journal of Education and Psychology in the Community, 5 (1\&2): 42-53.

Vontz, T. S., Metcalf, K. K. \& Patrick, J. J. (2000). Project Citizen and the Civic Development of Adolescent Students in Indiana, Latvia, and Lithuania. Indiana: Indiana University ERIC, Educational Resources Information Center.

Winataputra, U, S. (2001). Jatidiri Pendidikan Kewarganegaraan Sebagai Wahana Sistemik Pendidikan Demokrasi. Disertasi Doktor pada Sekolah Pascasarjana Universitas Pendidikan Indonesia Bandung: tidak diterbitkan.

Woods, D. R. (2014). Problem-Oriented Learning, Problem-Based Learning, Problem-Based Synthesis, Process Oriented Guided Inquiry Learning, Peer-Led Team Learning, Model-Eliciting Activities, and Project-Based Learning: What Is Best for You? 53 (13), Industrial \& Engineering Chemistry, 53 (13): 5337-535. 